\title{
First report of (U-Th)/He thermochronometric data across Northeast Japan Arc: implications for the long-term inelastic deformation
}

\author{
Shigeru Sueoka ${ }^{1 *}\left(\mathbb{D}\right.$, Takahiro Tagami $^{2}$ and Barry P. Kohn ${ }^{3}$
}

\begin{abstract}
(U-Th)/He thermochronometric analyses were performed across the southern part of the Northeast Japan Arc for reconstructing the long-term uplift and denudation history in the region. Apatite (U-Th-Sm)/He ages ranged from 64.3 to $1.5 \mathrm{Ma}$, while zircon (U-Th)/He ages ranged between 39.6 and 11.0 Ma. Apatite (U-Th-Sm)/He ages showed obvious contrast among the morphostructural provinces; older ages of 64.3-49.6 Ma were obtained in the Abukuma Mountains on the fore-arc side, whereas younger ages of 11.4-1.5 Ma were determined in the Ou Backbone Range (OBR) along the volcanic front and the Asahi Mountains on the back-arc side. The age contrasts are basically interpreted to reflect the differences in the uplift and the denudation histories of the provinces considering the thermal effects of magmatism and timing of the known uplift episodes. Denudation rates were calculated to be $<0.1 \mathrm{~mm} /$ year in the Abukuma Mountains, 0.1 to $1 \mathrm{~mm} /$ year in the Ou Backbone Range, and $\sim 0.1$ to $0.3 \mathrm{~mm} /$ year in the Asahi Mountains. The denudation rates tend to increase from the mountain base to the ridges in the OBR (and the Asahi Mountains). This relationship shows a contrast with the previous findings in fault-block mountains in the Southwest (SW) Japan Arc, where the highest denudation rates were estimated near fault(s) along the base(s). This observation might reflect a difference in mountain uplift mechanisms between the NE and the SW Japan Arcs and imply that thermochronometric approaches are useful for constraining uplift and denudation histories at the scale of an island arc, as well as continental orogens. However, careful discussion of magmatic thermal effects is required.
\end{abstract}

Keywords: (U-Th)/He thermochronometry, Denudation, Inelastic deformation, Northeast Japan Arc

\section{Introduction}

The paradox of deformation is well known in the Northeast (NE) Japan Arc; short-term deformation observed by geodetic techniques and long-term deformations estimated from geomorphic/geologic data differ both in rate and direction (e.g., Hashimoto 1990; Ikeda 1996). The discrepancy between the short- and the long-term deformations is expected to be balanced by a supercycle earthquake along the Japan Trench (Ikeda 1996), but it was not balanced by the co-seismic deformation

\footnotetext{
*Correspondence: sueoka.shigeru@jaea.go.jp

1 Tono Geoscience Center, Japan Atomic Energy Agency, 959-31, Jorinji, Izumi-cho, Toki, Gifu 509-5102, Japan

Full list of author information is available at the end of the article
}

of the 2011 Tohoku-oki mega earthquake (Mw9.0) (e.g., Ozawa et al. 2011; Ikeda et al. 2012; Nishimura 2014). A few revised models have suggested that the paradox may be resolved by taking into account post-seismic deformation (e.g., Ikeda et al. 2012). For solving the paradox comprehensively, that is, for creating a more detailed understanding of the strain buildup/release process in an arc-trench system, it is essential to discriminate between elastic and inelastic deformation from geodetic data; elastic deformation is canceled by earthquake cycles, whereas inelastic deformation contributes to orogenesis (e.g., Ikeda 2014). For discriminating between elastic and inelastic deformation, it is effective to estimate inelastic deformation by using geological/geomorphological approaches (e.g., Ikeda et al. 2012; Ikeda 2014). 
In this paper, we report the results of the first systematic thermochronometric investigation across NE Japan Arc for quantitative reconstruction of its vertical inelastic deformation over the last $10^{6}$ years or longer. Thermochronometry, e.g., (U-Th)/He, and fission-track (He and FT, respectively) are useful to reconstruct the denudation history of mountain ranges over the past approximately $10^{6}-10^{8}$ years (e.g., Reiners and Brandon 2006). However, thermochronometric methods are more difficult to apply to Japanese mountains because these mountains are generally as young as $10^{6}$ years and relatively subdued topographically; the total denudation related to the ongoing mountain building is generally too low to detect (Sueoka et al. 2015, 2016). However, owing to the recent development of low-temperature thermochronometry, uplift and denudation histories of fault-block mountains in the Southwest (SW) Japan Arc over the past few million years have been successfully constrained (e.g., Sueoka et al. 2011, 2012; see also review of Sueoka et al. 2016). The mountains in the NE Japan Arc are more challenging than those in the SW Japan Arc in terms of the applicability of thermochronometry because of their relatively low topographic relief, widespread late Cenozoic volcanism (e.g., Committee for Catalog of Quaternary Volcanoes in Japan 1999; Yoshida 2009; Yoshida et al. 2013), complicated geothermal structures (e.g., Tanaka et al. 2004), and smaller exposure of bedrock due to thick sediment deposition during opening of the Sea of Japan in the middle Miocene (e.g., Wakita et al. 2009). Our goals are to reconstruct the uplift and denudation histories of the mountains in the NE Japan Arc for understanding vertical inelastic deformations, and to demonstrate the applicability and usefulness of thermochronometric methods in an island arc setting, where uplift is brought by plate subduction different from a continental collision zone.

\section{Geology and geomorphology}

The NE Japan Arc largely consists of three morphostructural provinces, namely mountains on the back-arc side (e.g., Dewa Hills, Asahi Mountains, and Iide Mountains), Ou Backbone Range (OBR) along the volcanic front, and mountains on the fore-arc side (e.g., Kitakami Mountains and Abukuma Mountains) (Fig. 1), providing a typical island arc setting (e.g., Minoura and Hasegawa 1992; Yoshida et al. 2013). The mountains on the forearc side are relatively wide, have gentle slopes, and lowrelief surfaces (Fig. 1b). The OBR is a narrow and long mountain range wedged between active faults (Fig. 1a). Quaternary volcanism is dominant in the OBR and in a few parts of the back-arc side (Fig. 1a). The NE Japan Arc generally shows arc-parallel structures, for example, mountain ranges, active faults, and volcanic chains, although across-arc mountains and chains of volcanoes are also observed on the back-arc side (e.g., Tamura et al. 2002).

The NE and the SW Japan Arcs were formed as a result of opening of the Sea of Japan at 25-15 Ma, although they had originally been parts of the East Asian continental margin (e.g., Otofuji et al. 1985; Jolivet et al. 1994; Yanai et al. 2010). During the opening of the Sea of Japan, normal faulting due to back-arc rifting was prevalent (e.g., Sato 1994). A substantial number of the Miocene normal faults were reactivated as reverse faults under the strong $\mathrm{E}-\mathrm{W}$ compression over the last few million years, known as the inversion tectonics (e.g., Sato 1994; Okamura et al. 1995; Okada and Ikeda 2012). Presently, the NE Japan Arc is also characterized by the thin-skinned tectonics owing to the presence of thick sediments and volcanic products formed during the opening of the Sea of Japan (e.g., Sato and Kato 2010; Okada and Ikeda 2012).

A few studies have been conducted to reveal the uplift and denudation histories of the mountains in the NE Japan Arc, but the available literatures are still somewhat limited. Only a few sets of thermochronometric studies on the back-arc side and the OBR are available (Fig. 1a). On the basis of sedimentary facies analyses, three uplift stages were identified in the OBR as (1) surface uplift and regional unconformity (12-9 Ma), (2) differential uplift and compression (6.5-3 Ma), and (3) uplift and intense compression (after $\sim 3 \mathrm{Ma}$ ) (Nakajima et al. 2006; Nakajima 2012, 2013). In addition, uplift stages in the Dewa Hills and the Asahi Mountains on the back-arc side were constrained by analyzing sedimentary facies in the adjacent Shinjo basin, suggesting that the oldest uplift phase of the Asahi Mountains occurred at $\sim 5 \mathrm{Ma}$ and then the Dewa Hills began to uplift over the Pliocene (Moriya et al. 2008). By contrast, in the Kitakami and the Abukuma Mountains on the fore-arc side, remnants of uplifted peneplains can be seen at elevations of $~ 300$ to 1200 m (e.g., Nakamura 1963; Koike 1969; Kimura 1994). Furthermore, relatively old FT Cretaceous ages of apatite and zircon have been reported in the Kitakami and the Abukuma Mountains (Goto 2001; Ohtani et al. 2004) (Fig. 1a). Together, these imply relatively stable thermal and tectonic conditions over the Cenozoic with recent minor uplift episode(s).

\section{Methods}

(U-Th)/He thermochronometers have relatively low closure temperatures, $\sim 55$ to $80^{\circ} \mathrm{C}$ for apatite (Flowers et al. 2009; Gautheron et al. 2009) and 160 to $200{ }^{\circ} \mathrm{C}$ for zircon (Guenthner et al. 2013), compared to the other major thermochronometers (see Table 1 of Reiners et al. 2005). Thus, He thermochronometers offer an advantage in detecting relatively small amounts of cooling related to recent mountain building in the NE Japan Arc. Samples 


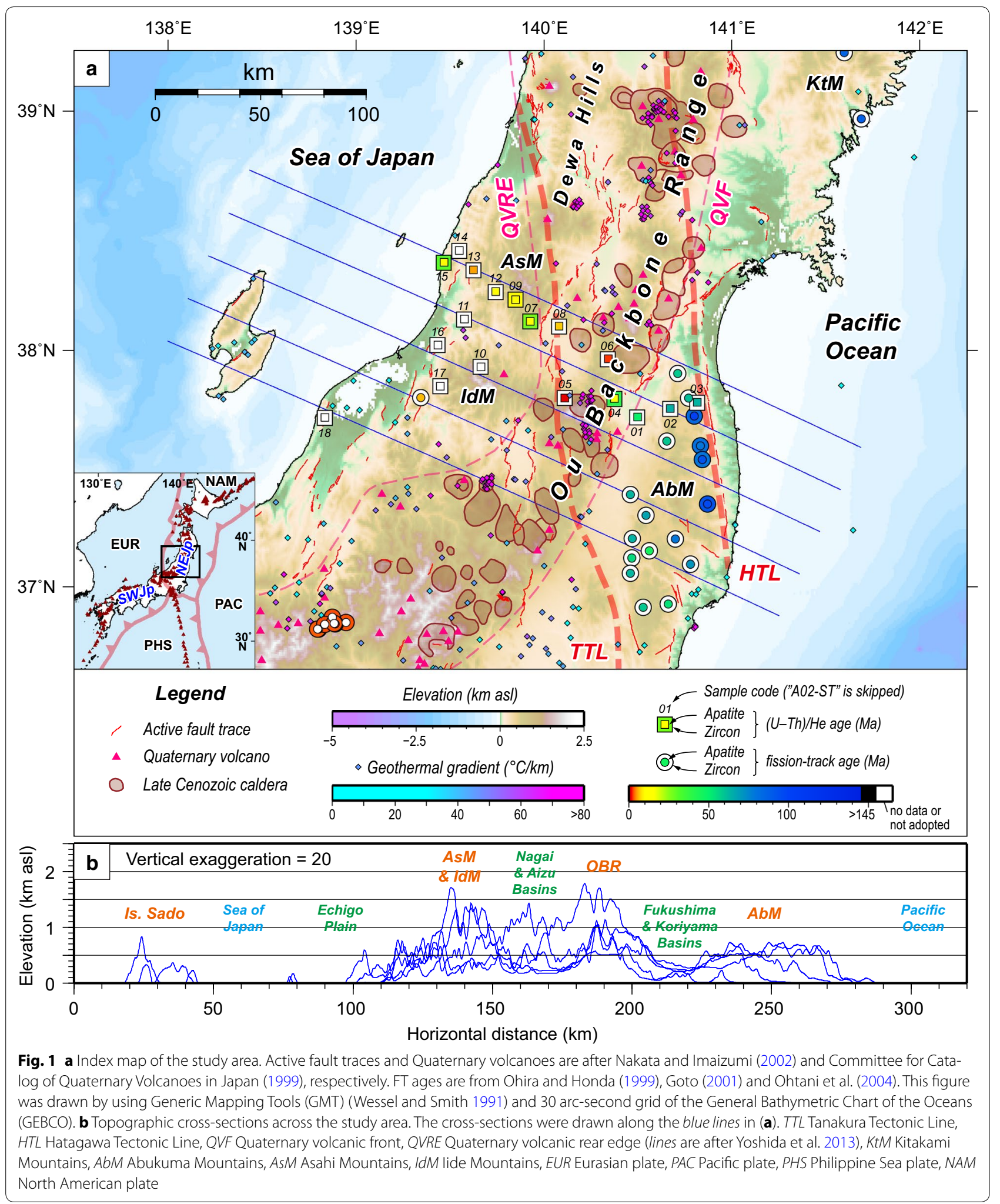


Table 1 Summary of sample parameters

\begin{tabular}{|c|c|c|c|c|c|c|c|c|}
\hline \multirow[t]{2}{*}{ Sample } & \multirow[t]{2}{*}{ Region } & \multirow[t]{2}{*}{ Rock type } & \multirow[t]{2}{*}{$\begin{array}{l}\text { E-lon. } \\
\text { (deg.) }\end{array}$} & \multirow[t]{2}{*}{$\begin{array}{l}\text { N-lat. } \\
\text { (deg.) }\end{array}$} & \multirow[t]{2}{*}{$\begin{array}{l}\text { Elv. } \\
\text { (m asl) }\end{array}$} & \multicolumn{2}{|c|}{$\begin{array}{l}\text { Weighted mean } \mathrm{He} \\
\text { age } \pm 95 \% \mathrm{Cl} \\
(\mathrm{Ma})\end{array}$} & \multirow[t]{2}{*}{$\begin{array}{l}\text { AHe } T_{c} \\
\left({ }^{\circ} \mathrm{C}\right)\end{array}$} \\
\hline & & & & & & Apatite & Zircon & \\
\hline A02-ST01 & $\mathrm{AbM}$ & $\mathrm{CrGr}$ & 140.49643 & 37.71979 & 96 & $49.6 \pm 3.0$ & & 51.9 \\
\hline A02-ST02 & $\mathrm{AbM}$ & $\mathrm{CrGr}$ & 140.67009 & 37.75609 & 300 & $64.3 \pm 9.5$ & & 51.4 \\
\hline A02-ST03 & $\mathrm{AbM}$ & $\mathrm{CrGr}$ & 140.81441 & 37.78157 & 172 & $63 \pm 15$ & & 50.6 \\
\hline A02-ST04 & OBR & $\mathrm{CrGr}$ & 140.37499 & 37.79742 & 282 & $11.2 \pm 1.4$ & $39.6 \pm 7.4$ & 62.0 \\
\hline A02-ST05 & OBR & $\mathrm{CrGr}$ & 140.11011 & 37.80026 & 620 & $1.5 \pm 0.1$ & N/A & 76.1 \\
\hline A02-ST06 & OBR & $\mathrm{CrGr}$ & 140.34019 & 37.96475 & 404 & $2.5 \pm 1.7$ & N/A & 72.1 \\
\hline A02-ST07 & AsM & $\mathrm{CrGr}$ & 139.92652 & 38.12244 & 434 & $10.3 \pm 0.6$ & $27.2 \pm 3.3$ & 63.8 \\
\hline A02-ST08 & OBR & $\mathrm{CrGr}$ & 140.07998 & 38.10221 & 236 & $6.8 \pm 0.9$ & N/A & 64.4 \\
\hline A02-ST09 & AsM & $\mathrm{CrGr}$ & 139.84943 & 38.21464 & 456 & $11.1 \pm 2.3$ & $11.0 \pm 2.4$ & 58.7 \\
\hline A02-ST12 & AsM & $\mathrm{CrGr}$ & 139.74319 & 38.24726 & 245 & $11.4 \pm 0.8$ & & 64.4 \\
\hline A02-ST13 & AsM & $\mathrm{CrGr}$ & 139.62478 & 38.33835 & 97 & $5.2 \pm 0.9$ & N/A & 68.5 \\
\hline A02-ST15 & AsM & $\mathrm{CrGr}$ & 139.46802 & 38.36962 & 44 & $9.7 \pm 0.7$ & $30.7 \pm 4.8$ & 63.8 \\
\hline
\end{tabular}

He ages are shown as weighted mean (see also Tables 2, 3). N/A denotes that weighted mean ages were not adopted. AHe $T_{\mathrm{c}}$ is the closure temperature of the AHe system considering the cooling rate of each sample; detailed calculations are shown in the body text

AbM Abukuma Mountains, OBR Ou Backbone Range, AsM Asahi Mountains, CrGr Cretaceous granitoid

were collected from Cretaceous granitic rocks across the southern part of the NE Japan Arc (Fig. 1a; Table 1). Mineral separations were conducted at Kyoto Fission-Track Co., Ltd., by using conventional methods based on heavy liquid and magnetic protocols.

(U-Th)/He analyses were carried out at University of Melbourne. These analyses followed the protocol of House et al. (2000) for laser extraction of helium from single grains for both apatite and zircon. Clear, nonfractured euhedral grains with average grain radii in a close size range were hand-picked under an Olympus SZX12 binocular microscope, then immersed in ethanol and checked under polarized light to detect and exclude grains with possible inclusions. Grain geometries were imaged microscopically, measured and stored for applying the $\alpha$-ejection correction (Farley et al. 1996) and then loaded into small, acid-treated platinum capsules.

Apatite grains were outgassed under vacuum at $\sim 900{ }^{\circ} \mathrm{C}$ for $5 \mathrm{~min}$, by using a Coherent Quattro FAP $820 \mathrm{~nm}$ diode laser with fiber-optic coupling to the sample chamber. Helium content was determined by isotope dilution against a pure ${ }^{3} \mathrm{He}$ spike, calibrated against an independent ${ }^{4} \mathrm{He}$ standard and measured using a Balzers quadrupole (Prisma QMS 200) mass spectrometer. Zircon samples were outgassed by applying laser power of $\sim 12.6 \mathrm{~W}\left(\sim 1300{ }^{\circ} \mathrm{C}\right)$ for $20 \mathrm{~min}$ to ensure complete extraction of ${ }^{4} \mathrm{He}$. A hot blank was run after each extraction to verify complete outgassing. Where possible, helium extractions were performed on single grains, but in cases where ${ }^{4} \mathrm{He}$ yields were too low, aliquots of multiple grains were analyzed.
The outgassed grains were removed from the laser chamber, and dissolved and analyzed for parent isotopes by using an Agilent 7700X ICP Mass Spectrometer. Zircon grains were removed from their Pt capsules, and transferred to Parr bombs where they were spiked with ${ }^{233} \mathrm{U}$ and ${ }^{229} \mathrm{Th}$ and digested in small volumes $(0.3-$ $0.5 \mathrm{ml}$ ) at $240{ }^{\circ} \mathrm{C}$ for $40 \mathrm{~h}$ in HF. Standard solutions containing the same spike amounts as those in the samples were treated identically, as were a series of unspiked reagent blanks. A second bombing in $\mathrm{HCl}$ for $24 \mathrm{~h}$ at $200{ }^{\circ} \mathrm{C}$ ensured dissolution of fluoride salts. The zircon solutions were then dried down, dissolved in $\mathrm{HNO}_{3}$, and diluted in $\mathrm{H}_{2} \mathrm{O}$ to $5 \%$ acidity for analysis of ${ }^{238} \mathrm{U},{ }^{235} \mathrm{U}$, and ${ }^{232} \mathrm{Th}$ by solution ICP-MS. $U$ and Th isotope ratios were measured to a precision of $<2 \%$, and overall precision of the zircon $\mathrm{He}$ ages was estimated to be $\sim 6 \%$ or lower. Zircon $\mathrm{He}$ ages were calculated and corrected for $\alpha$-emission following the approach of Hourigan et al. (2005). Fish Canyon Tuff zircons (Gleadow et al. 2015) were also run as "unknowns" with each batch of samples to check sample accuracy. Zircon He analytical data are listed in Table 2.

Apatites (still in their Pt capsules) were dissolved in $\mathrm{HNO}_{3}$ and analyzed for ${ }^{238} \mathrm{U},{ }^{235} \mathrm{U},{ }^{232} \mathrm{Th}$, and ${ }^{147} \mathrm{Sm}$. The analyses were calibrated using the reference material BHVO-1, and Mud Tank Carbonatite apatite, and international rock standard BCR-2 were used as check standards with each batch of samples analyzed. (U-Th-Sm)/ $\mathrm{He}$ ages were calculated and corrected for $\alpha$-emission following the approach of Farley et al. (1996). Analytical uncertainties at the Melbourne He facility were conservatively assessed to be $\sim 6.2 \%( \pm 1 \sigma)$, including the 


\begin{tabular}{|c|c|c|c|c|c|c|c|}
\hline $\bar{J} \frac{5}{2}$ & 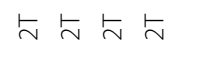 & 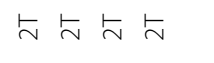 & 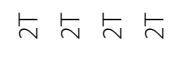 & 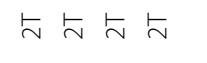 & 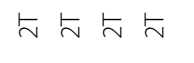 & $\llcorner\llcorner\llcorner\llcorner$ & $\hbar \hbar$ \\
\hline 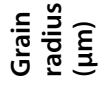 & $\overline{8} \overline{8}$ 品 & 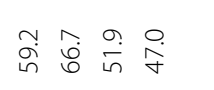 & 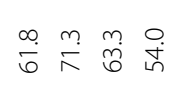 & 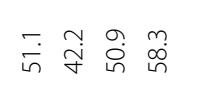 & & 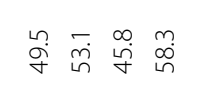 & กี่ \\
\hline 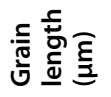 & 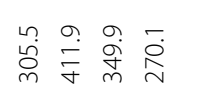 & 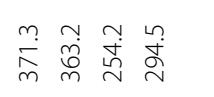 & 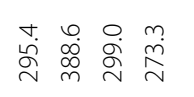 & 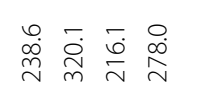 & 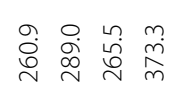 & 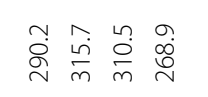 & 啇 令 \\
\hline 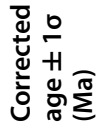 & 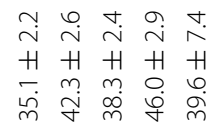 & 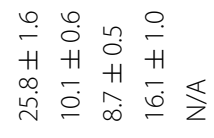 & 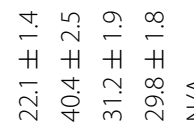 & 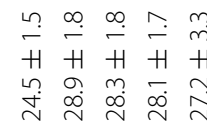 & 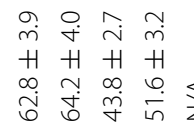 & 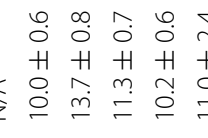 & 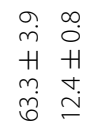 \\
\hline 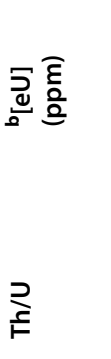 & 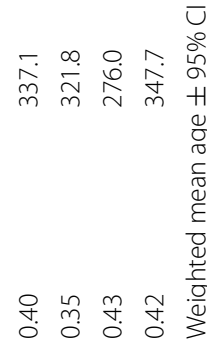 & 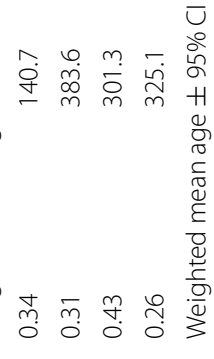 & 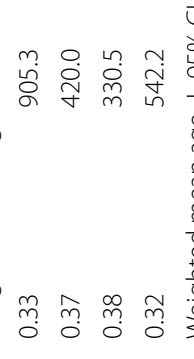 & 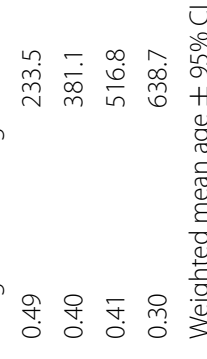 & 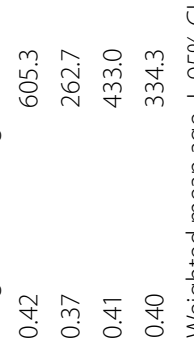 & 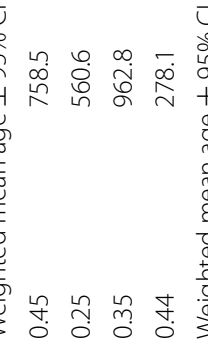 & 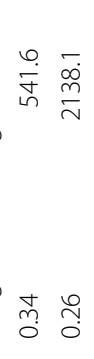 \\
\hline 它袞 & 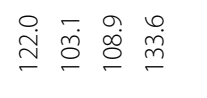 & 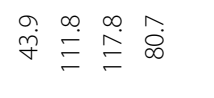 & 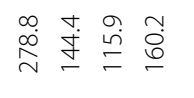 & 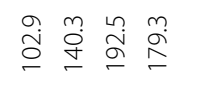 &  & 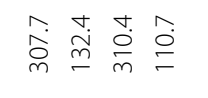 & 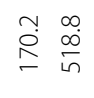 \\
\hline כ & 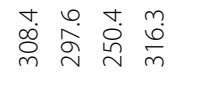 & 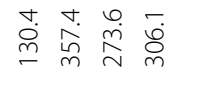 & 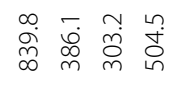 & 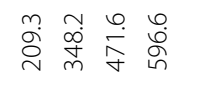 & 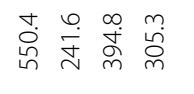 & 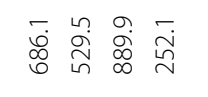 & 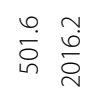 \\
\hline$\sum_{\pi}^{\pi}$ & 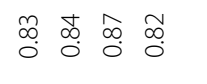 & 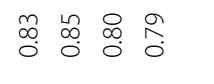 & $\begin{array}{cccc}\infty & \infty & \infty & \bar{c} \\
\infty & \infty & 0 & 0 \\
0 & 0 & 0 & 0 \\
0 & 0 & 0\end{array}$ & 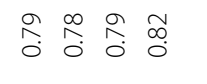 & 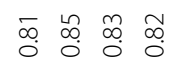 & 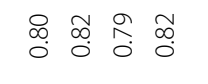 & $\begin{array}{ll}\infty & 0 \\
\infty & \infty \\
0 & 0 \\
0\end{array}$ \\
\hline 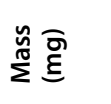 & 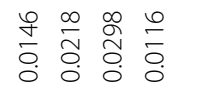 & 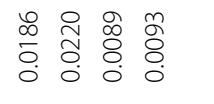 & 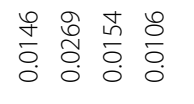 & 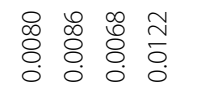 & 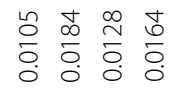 & 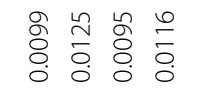 & $\begin{array}{ll}\bar{\infty} & \infty \\
\stackrel{0}{0} \\
0 \\
0\end{array}$ \\
\hline 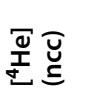 & 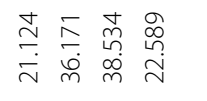 & 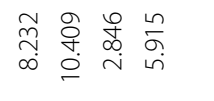 & 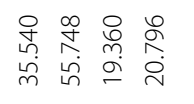 & 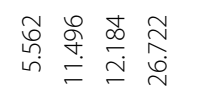 &  & 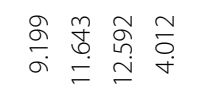 & 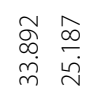 \\
\hline 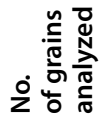 & ---- & ---- & ---- & ---- & ---- & ---- & -- \\
\hline $\begin{array}{l}\stackrel{\dot{\varphi}}{0} \\
\stackrel{\Xi}{x}\end{array}$ & 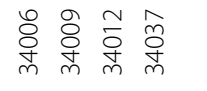 & 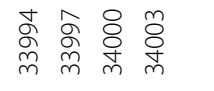 & 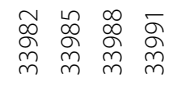 & 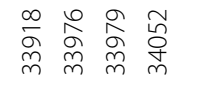 & 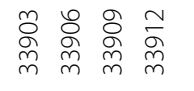 & 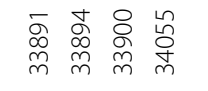 & 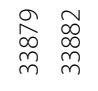 \\
\hline $\begin{array}{l}\stackrel{8}{c} \\
\stackrel{0}{0}\end{array}$ & 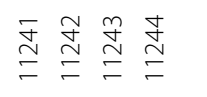 & 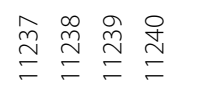 & 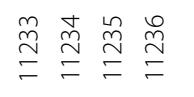 & 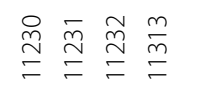 & 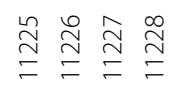 & 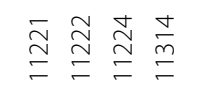 & $\stackrel{\stackrel{\infty}{\Xi} \stackrel{\infty}{\Xi}}{\Xi}$ \\
\hline$\frac{\varrho}{\frac{0}{\varrho}}$ & 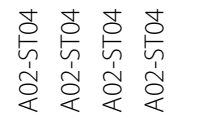 & 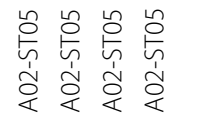 & 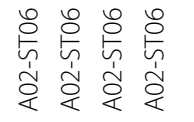 & 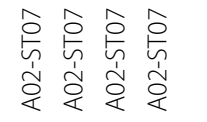 & 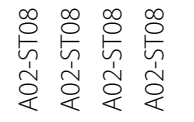 & 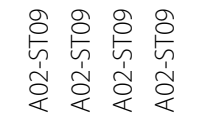 & 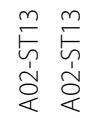 \\
\hline
\end{tabular}




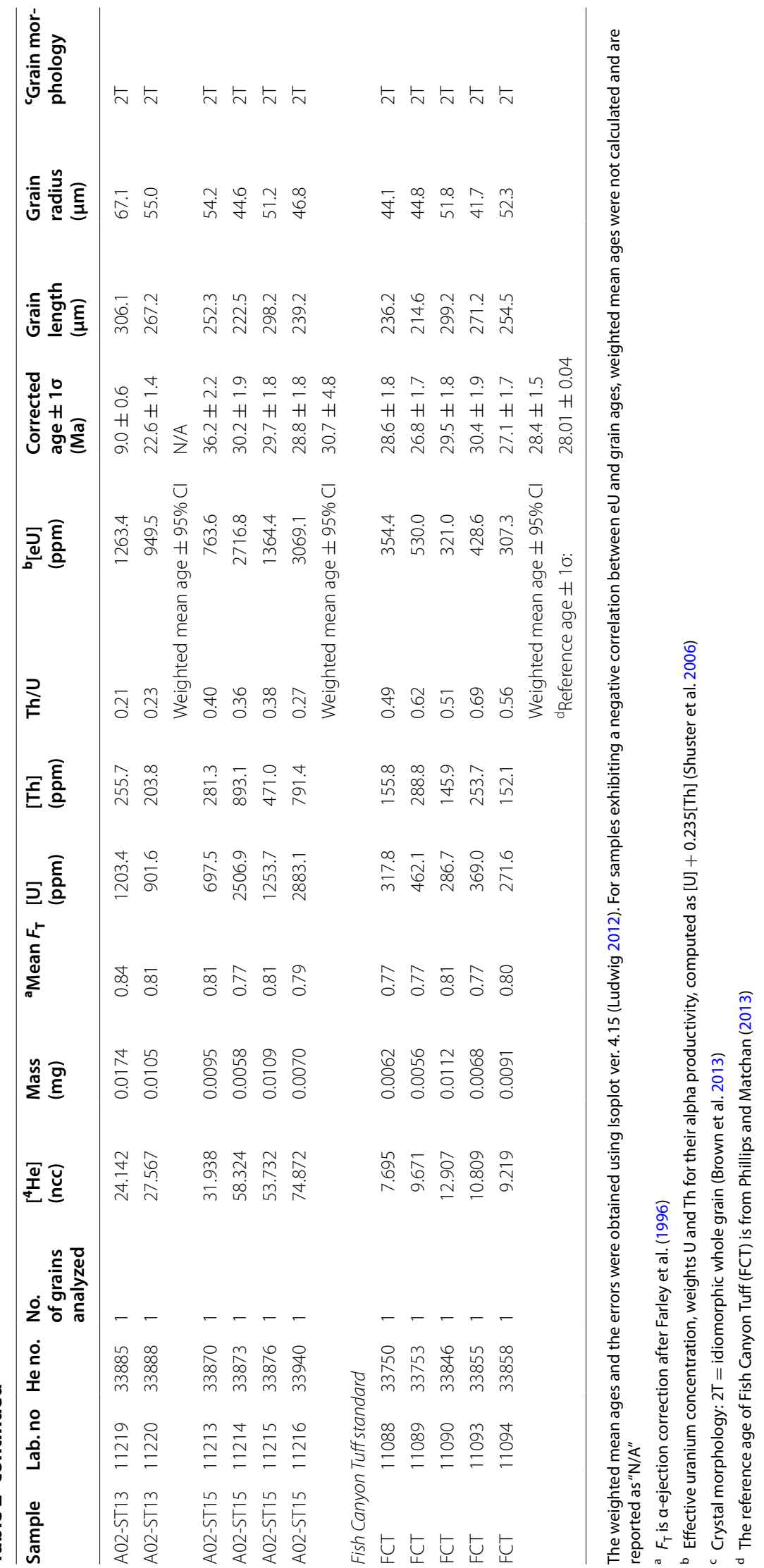


$\alpha$-ejection correction, an estimated $5 \mu \mathrm{m}$ of uncertainty in grain dimensions, gas analysis (estimated as $<1 \%$ ), and ICP-MS analytical uncertainties, but no possible heterogeneity in $U$ and Th distributions. The accuracy and precision of $\mathrm{U}, \mathrm{Th}$, and $\mathrm{Sm}$ contents range up to $2 \%$, but they are typically better than $1 \%$. Durango apatites (McDowell et al. 2005) were also run as "unknowns" with each batch of samples as a check for sample accuracy. Apatite He data are summarized in Table 3. Weighted mean ages and errors were calculated using Isoplot ver. 4.15 (Ludwig 2012).

\section{Dating results}

Zircon $\mathrm{He}$ and Apatite $\mathrm{He}$ (ZHe and $\mathrm{AHe}$, respectively) dating results are given in Tables 2 and 3, respectively. Simultaneous measurement of age standards, namely Durango apatite and Fish Canyon Tuff zircon, yielded reasonable ages overlapping with the reference ages within $\pm 1 \sigma$ (Tables 2 and 3), indicating accuracy of the dating results.

\section{Reproducibility of grain ages}

Although most of the samples indicated reasonable reproducibility of the grain ages, a few samples showed age dispersion greater than expected from the analytical uncertainties and statistical errors (Tables 2, 3; Figs. 2, 3). Apatite and zircon $\mathrm{He}$ ages represent the integration of different parameters, such as, grain size (Farley 2000), possible zoning of the parent nuclides (Hourigan et al. 2005), radiation damage (Shuster et al. 2006; Flowers et al. 2009; Gautheron et al. 2009; Guenthner et al. 2013), $\mathrm{U}$ - and/or Th-rich mineral inclusions in apatite (Vermeesch et al. 2007), implantation of ${ }^{4} \mathrm{He}$ in apatite from the adjacent minerals (Spiegel et al. 2009), grain fragmentation (Brown et al. 2013; Beucher et al. 2013), chemical composition of apatite (Gautheron et al. 2013), and trapping of radiometric $\mathrm{He}$ in fluid inclusions (Danišík et al. 2017). Thus, samples with significant age dispersion reflect slow cooling or a complicated cooling history rather than simple rapid cooling because effects of these parameters are magnified by slow or complicated cooling history (e.g., Gautheron et al. 2009; Brown et al. 2013; Danišík et al. 2017).

For apatite samples, grain ages generally reproduced reasonably well (Fig. 3), suggesting a simple and relatively rapid cooling history around the closure temperature of the AHe system. Although samples A02-ST03, 04, 06, 09, 12,13 , and 15 contain one or two grains with ages dispersed from the other grains, at least, radiation damage cannot explain the age dispersion sufficiently; because closure temperature of the AHe system increases with effective uranium (eU) (Flowers et al. 2009), eU and grain age should have a positive correlation if the dispersion is derived from radiation damage (cf Fig. 3). Within samples, we adopted grain ages that overlapped with the other grain ages within $\pm 3 \sigma$ to calculate the weighted mean age of each sample (Table 3; Fig. 3). For A02-ST03, grain ages present a cluster ranging $80-50 \mathrm{Ma}$, except for one grain yielding an age of $225 \mathrm{Ma}$. However, all of the grain ages belonging to the cluster do not overlap within $\pm 3 \sigma$. Therefore, we rejected only the grain of $\sim 225 \mathrm{Ma}$ and obtained a weighted mean age of $63 \pm 15 \mathrm{Ma}$. This age is concordant with that of the closest locality, A02-ST02 (64.3 $\pm 9.5 \mathrm{Ma})$ (Table 1).

For zircon samples, grain age dispersions are more obvious in a few samples. Four samples, namely A02-ST04, 07, 09, and 15, indicated reasonable reproducibility (within $\pm 3 \sigma$ ), and weighted mean ages were obtained (Table 2; Fig. 2). These four samples are thought to reflect a simple rapid cooling history around the closure temperature of the $\mathrm{ZHe}$ system. By contrast, the other four samples, A02-ST05, 06, 08, and 13, yielded scattered grain ages (Table 2; Fig. 2). In these four samples, the grain ages showed a negative correlation with $\mathrm{eU}$, a proxy for radiation damage of crystals (Guenthner et al. 2013), suggesting a slower or more complicated cooling history than the other samples. Thus, we did not calculate the weighted mean ages of the four samples since closure temperature of the zircon He system may vary with eU (Guenthner et al. 2013).

\section{Comparison with previous FT ages}

AHe ages range from 64.3 to $1.5 \mathrm{Ma}$ in terms of weighted mean age, showing an obvious contrast among the morphostructural provinces. The ages in the Abukuma Mountains range are 64.3-49.6 Ma, whereas those in the OBR and the Asahi Mountains are between 11.4 and $1.5 \mathrm{Ma}$ (Table 3; Fig. 4a). In the Abukuma Mountains on the fore-arc side, apatite FT ages of 100.0-46.0 Ma have been reported (Goto 2001; Ohtani et al. 2004) (Fig. 1a). Thus, our apatite He dating results agree well with the previously determined FT ages. Apatite FT ages are expected to be older than or equal to the corresponding apatite $\mathrm{He}$ ages because the closure temperature of the apatite FT system $\left(90-120{ }^{\circ} \mathrm{C}\right.$ for general composition; Ketcham et al. 1999) is slightly higher than that of the apatite He system $\left(55-80{ }^{\circ} \mathrm{C}\right.$; Flowers et al. 2009; Gautheron et al. 2009). Although no apatite FT age was reported in the OBR and the Asahi Mountains on the back-arc side, an apatite FT age of $6.1 \pm 0.8(1 \sigma)$ Ma was obtained in the Gozu Mountains (Goto 2001) (see apatite FT age to the west of A01-ST17 in Fig. 1a). A direct comparison between the apatite FT age with our apatite He ages is difficult because the sampling localities belong to different mountain ranges. However, both cases commonly suggest rapid post Middle Miocene cooling on the 







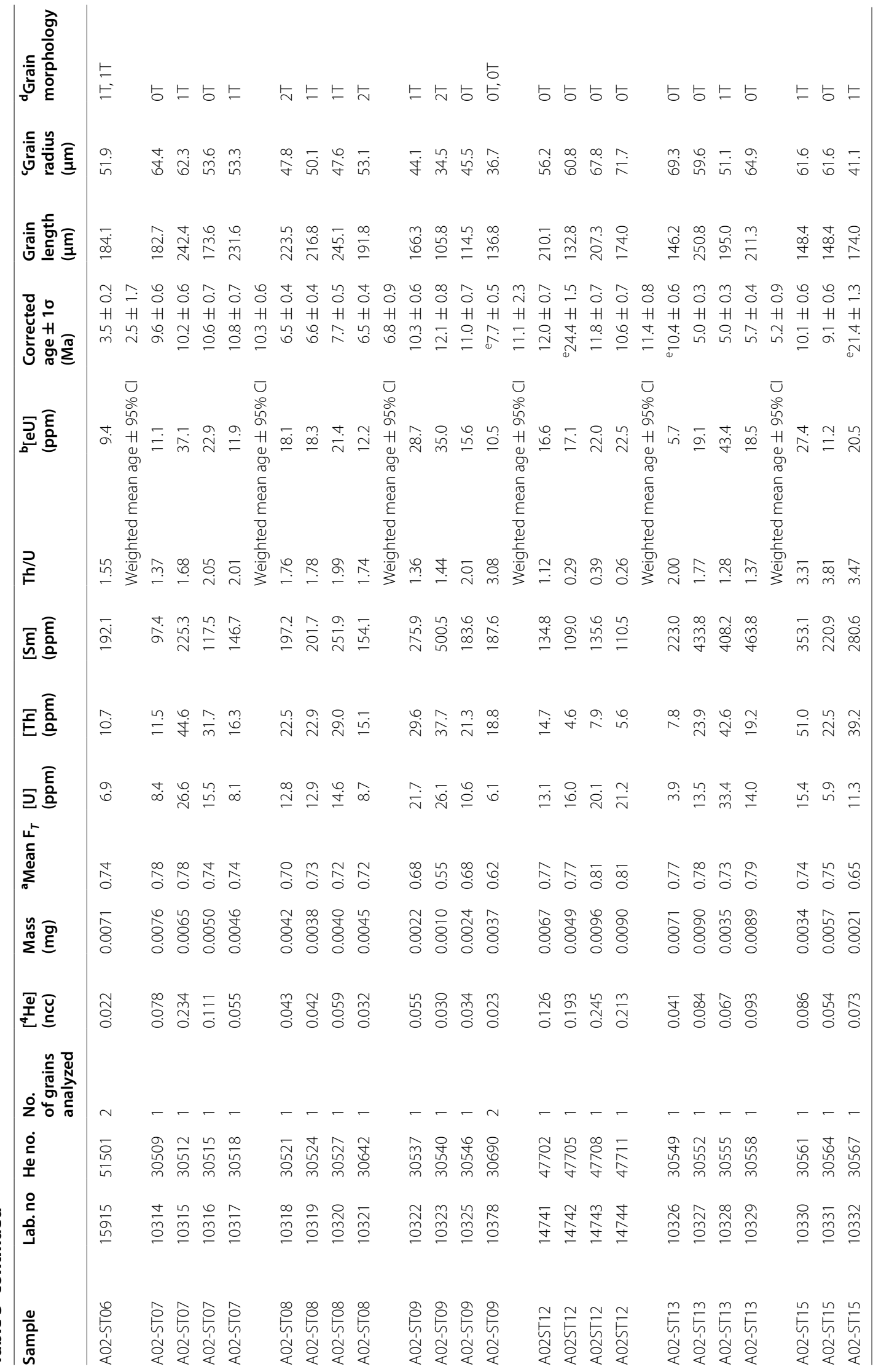




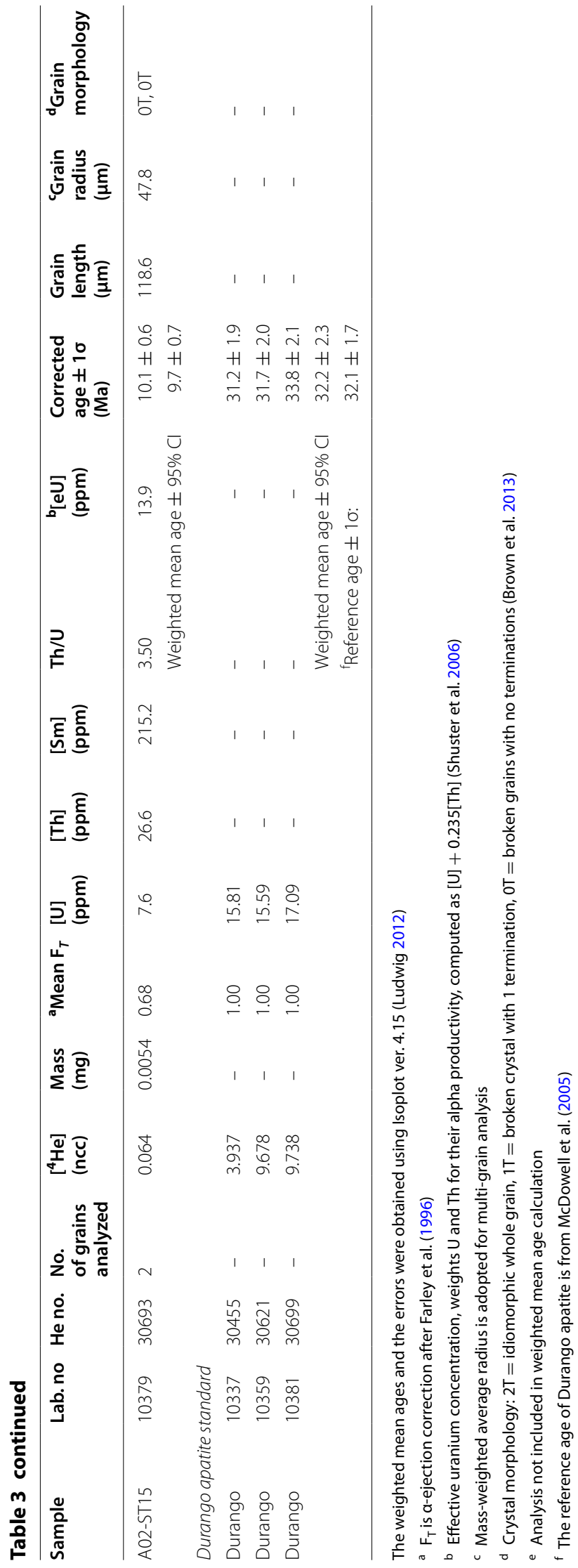

back-arc side and thus do not conflict with one another. Therefore, these observations indicate the accuracy of the $\mathrm{He}$ dating results. The weighted mean ages of $\mathrm{ZHe}$ are 39.6-11.0 Ma, although they were obtained in the OBR and the Asahi Mountains, not in the Abukuma Mountains. ZHe ages are older than or equal to the corresponding $\mathrm{AHe}$ ages, which is consistent with the predicted difference in closure temperatures $\left(160-200{ }^{\circ} \mathrm{C}\right.$ for ZHe system; Guenthner et al. 2013).

\section{Geological implications Interpretation of apparent He ages}

In terms of He ages, the OBR and the Asahi Mountains are significantly younger than the formation ages of the granitic bodies in Cretaceous. In addition, the AHe ages of the Abukuma Mountains are younger than or equal to the apatite FT ages of 100.0-46.0 Ma and younger than the zircon FT ages of 102.0-79.2 Ma reported previously in this region (Goto 2001; Ohtani et al. 2004). Therefore, these apparent $\mathrm{He}$ ages obviously reflect cooling events post-granitoid intrusions. These apparent $\mathrm{He}$ ages can be interpreted as (A) cooling ages following total thermal resetting, (B) cooling ages following cooling from temperatures which only partially reset the He clocks, or (C) mixed ages of multiple populations. Possibility (C) is rejected for the following reasons: (1) the samples were homogeneous granitoids so all grains should have a common thermal history, and (2) as discussed above, reproducibility of the grain ages is generally reasonable (within analytical uncertainties) and over-dispersed samples/grain ages were not included for calculating the weighted mean ages. By contrast, making a distinction between (A) and (B) is difficult owing to the lack of a precise thermal analysis methodology based on He ages. Nonetheless, the He ages definitely indicate that the last cooling events occurred at or after the apparent age; in other words, the ages denote the oldest limit of the last cooling events.

\section{Thermal disturbance due to volcanism}

Before reconstructing the regional denudation histories from the cooling ages, possible local thermal effects on ages due to volcanism should be discussed. In the NE Japan Arc, Quaternary volcanoes are distributed along the OBR and parts of the Dewa Hills (e.g., Committee for Catalog of Quaternary Volcanoes in Japan 1999; Tamura et al. 2002). Therefore, the geothermal structure of the NE Japan Arc is complex and quite different from region to region (Fig. 1a). Geothermal gradients on the fore-arc side commonly range 20 to $40{ }^{\circ} \mathrm{C} / \mathrm{km}$ (Tanaka et al. 2004). However, slightly higher geothermal gradients of $\sim 30$ to $60{ }^{\circ} \mathrm{C} / \mathrm{km}$ are observed in the OBR and on the back-arc side (Tanaka et al. 2004). Anomalous 

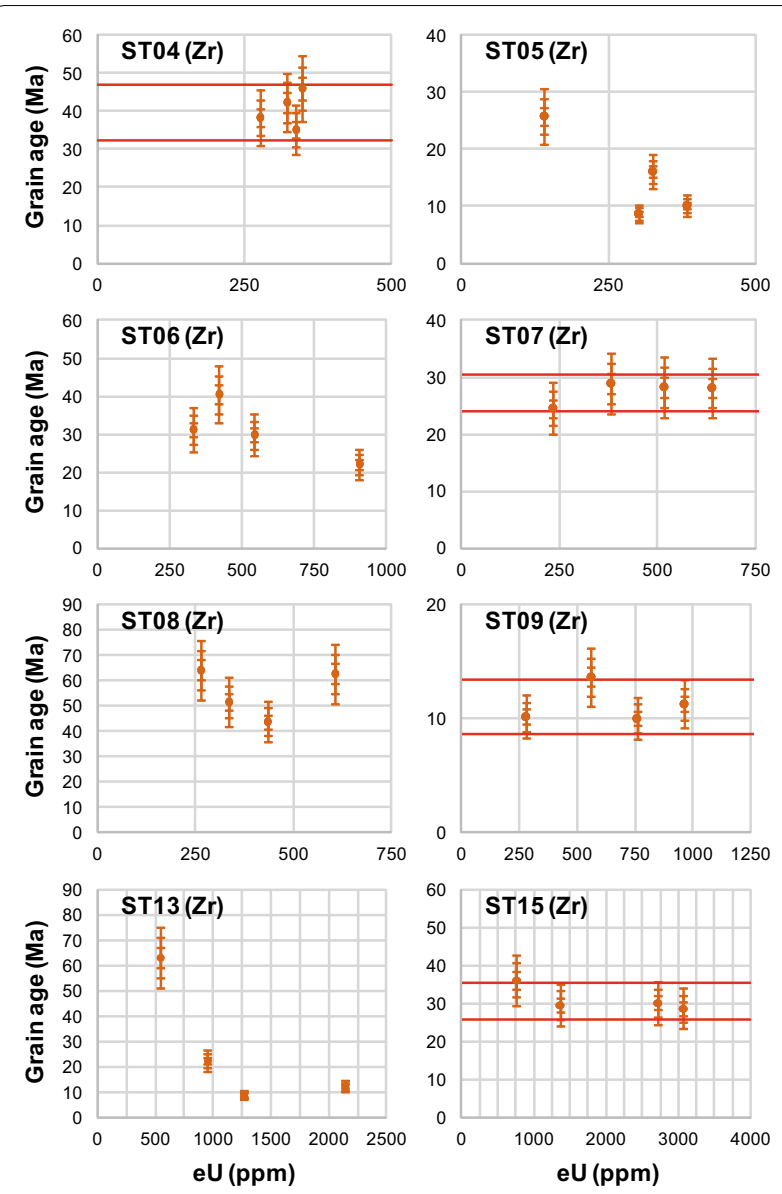

Fig. 2 Effective uranium (eU) versus (U-Th)/He grain age of zircon. The vertical error bars denote the $\pm 1 \sigma, \pm 2 \sigma$, and $\pm 3 \sigma$ ranges. The two horizontal red lines indicate the weighted mean age $+95 \%$ confidence interval $(\mathrm{Cl})$ and $-95 \% \mathrm{Cl}$, respectively

geothermal gradients $>100{ }^{\circ} \mathrm{C} / \mathrm{km}$ were also reported at some spots along the OBR, for instance, around the Quaternary volcanoes (Tanaka et al. 2004).

However, no Quaternary volcano has been reported around the sampling sites in the Asahi and the Abukuma Mountains (Fig. 1a). Furthermore, all of the dated samples were collected at a distance of $>10 \mathrm{~km}$ from the Quaternary volcanoes (Fig. 1a). This is important because on the basis of a compilation of temperature logging data of boreholes, Umeda et al. (1999) demonstrated that geothermal disturbance around major volcanoes in Japan is observed generally at $<10-20 \mathrm{~km}$ from their centers. In fact, geothermal gradients around the sampling sites are equivalent to the background level (Figs. 1a, 4b). Thus, we conclude that the He ages presented in this work have not been affected by any thermal disturbances derived from Quaternary volcanism.

In addition to the Quaternary volcanoes, $>80$ late Cenozoic calderas were distributed along the OBR
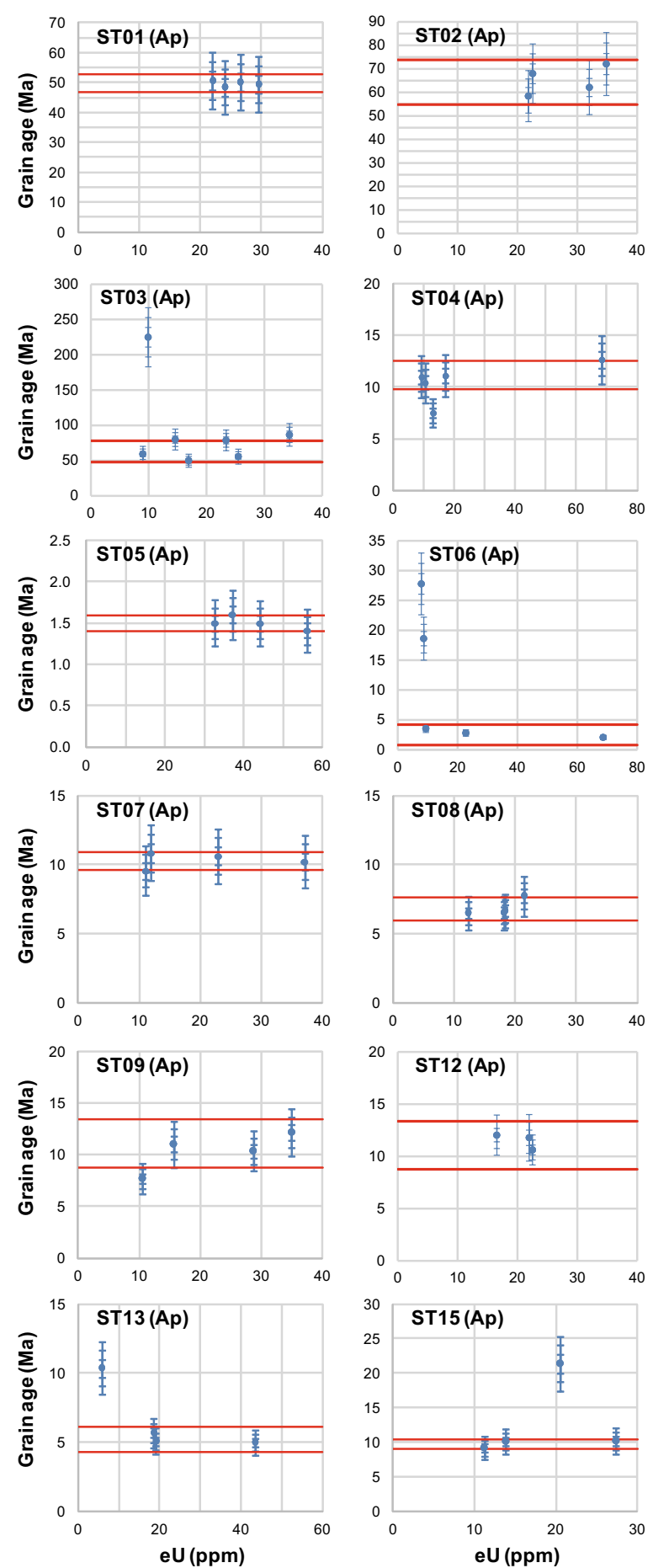

Fig. 3 Effective uranium (eU) versus (U-Th-Sm)/He grain age of apatite. The vertical error bars denote the $\pm 1 \sigma, \pm 2 \sigma$, and $\pm 3 \sigma$ ranges. The two horizontal red lines indicate the weighted mean age $+95 \%$ confidence interval $(\mathrm{Cl})$ and $-95 \% \mathrm{Cl}$, respectively

(Fig. 1a), formed mainly at 8-3.5 Ma under a NESW compressional stress regime (e.g., Yoshida 2009; Yoshida et al. 2013). These calderas might have had a 


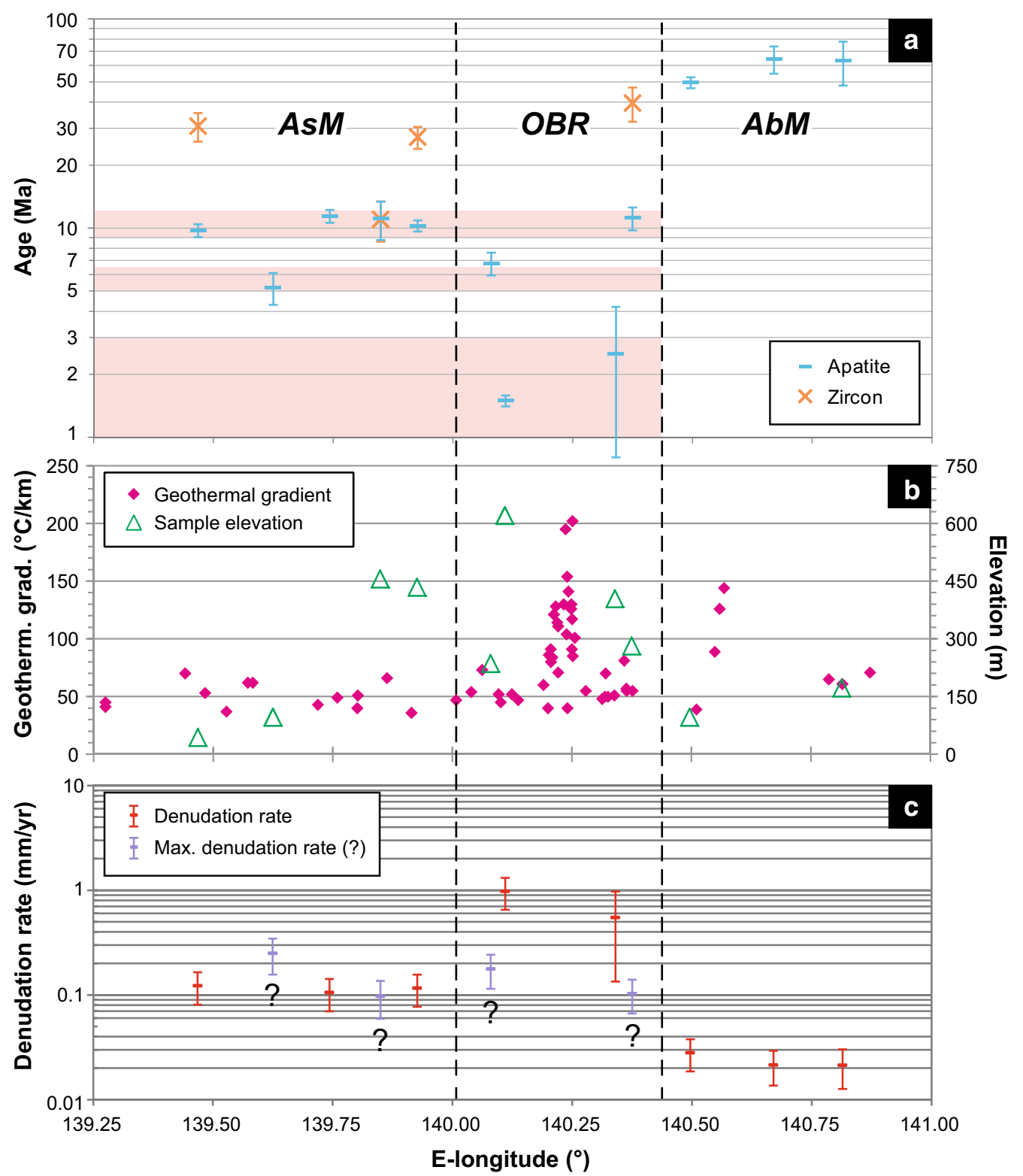

Fig. 4 a Longitude versus (U-Th)/He age. The weighted mean ages $\pm 95 \%$ confidence intervals are shown. The light pink bands indicate approximate range of timing of the three major recent uplift episodes of the NE Japan Arc in 12-9 Ma, 6.5-5 Ma, and after 3 Ma (e.g., Nakajima et al. 2006; Fujiwara et al. 2008; Moriya et al. 2008). b Longitude versus geothermal gradient and sample elevation. Geothermal gradient data of $37.5^{\circ} \mathrm{N}-38.5^{\circ} \mathrm{N}$ from Tanaka et al. (2004) are plotted. c Mean denudation rates calculated from AHe ages. Purpuric data shown with "?" indicate less reliable denudation rates which might reflect reheating related to magmatism; the computed denudation rates are thought to indicate the maximum value

thermal effect on the He ages of samples A02-ST04, 05, 06 , and 08 obtained from the OBR. However, the AHe ages of A02-ST05 and 06 are significantly younger than 8-3.5 Ma, which are the formation ages of the calderas, indicating that they reflect later cooling episodes than the aforementioned volcanism. By contrast, the AHe ages of the A02-ST04 and the 08 samples and all of the ZHe grain ages in the OBR, including the samples for which weighted mean ages were not calculated, are older than the caldera age. Thus, it is difficult to eliminate the possibility of reheating due to volcanism because short-term and/or low-temperature reheating events may cause partial resetting of the ages, yielding apparent ages older than the timing of the reheating. Similarly, the AHe age of $5.2 \pm 0.9$ Ma obtained for A02-ST13 might reflect partial resetting due to reheating because the Myojin-iwa 
andesite at $\sim 3 \mathrm{Ma}$ (Kondo et al. 2000) is distributed near the locality. A02-ST09 may also potentially have been reheated because the $\mathrm{AHe}$ and the $\mathrm{ZHe}$ ages overlap within the error range; such rapid and major cooling is difficult to explain by a denudation episode considering the general tectonic history of the NE Japan Arc since the middle Miocene.

\section{Uplift and denudation episodes of mountains in southern NE Japan Arc}

By analyzing the sedimentary facies in the adjacent basins, uplift episodes since the middle Miocene were identified on the back-arc side at $>5 \mathrm{Ma}$ and post $\sim 3 \mathrm{Ma}$ (e.g., Sato et al. 2004; Moriya et al. 2008) and in the OBR at 12-9 Ma, $\sim 6.5 \mathrm{Ma}$, and post $\sim 3 \mathrm{Ma}$ (e.g., Nakajima et al. 2006; Fujiwara et al. 2008; Nakajima 2012, 2013). The AHe and the ZHe ages younger than $15 \mathrm{Ma}$ overlap with the three known uplift stages (Fig. 4a). Therefore, these $<\sim 15 \mathrm{Ma}$ ages are basically interpreted to reflect episodes of cooling related to uplift and subsequent denudation since the opening of the Sea of Japan. Even though some of the He ages might reflect a cooling from the temperatures at which He ages partially reset, it is likely that the cooling was derived from one of the three uplift stages. Because the apparent ages indicate the oldest limit of the cooling event age, the cooling events prior to the middle Miocene cannot be reflected by the $<\sim 15 \mathrm{Ma}$ ages. Furthermore, reheating due to volcanism is less possible for these samples as discussed in the previous section. The ages that might reflect reheating, as discussed in the previous section, are also in accord with the timing of known uplift episodes; these data may thus potentially reflect denudation episodes but are less reliable. Therefore, these data are used as reference values in the following discussions about denudation histories. The $\mathrm{AHe}$ ages on the fore-arc side, namely A02-ST01, 02, and 03 , were interpreted to reflect the long-term denudation histories because there is no Quaternary volcano and/or late Cenozoic calderas in this area (Fig. 1a).

The AHe and the ZHe ages interpreted to reflect denudation histories indicate an obvious contrast among the three morphostructural provinces (Fig. 4a). This contrast is thought to indicate differences in the uplift and denudation histories among the provinces. The fore-arc side has been stable tectonically and thermally over the Cenozoic; denudation over this duration was calculated to be lower than $1-2 \mathrm{~km}$ assuming a general geothermal gradient of $\sim 30{ }^{\circ} \mathrm{C} / \mathrm{km}$ and surface temperature of $\sim 15{ }^{\circ} \mathrm{C}$ considering the closure temperature of the $\mathrm{AHe}$ system at $\sim 55$ to $80{ }^{\circ} \mathrm{C}$. This estimate is consistent with the previous geomorphic observation; the presence of low-relief erosion surfaces on the Abukuma Mountains implies that peneplanation related to slow denudation for a long period was dominant before the Quaternary uplift (e.g., Kimura 1994). By contrast, the back-arc side and the volcanic front were uplifted after the opening of the Sea of Japan in the middle Miocene, leading to AHe and $\mathrm{ZHe}$ ages younger than $\sim 15 \mathrm{Ma}$. The onset of the uplift of the Asahi Mountains is considered to predate that of the Dewa Hills, which is $\sim 5 \mathrm{Ma}$ at the latest (Moriya et al. 2008). However, the He ages obtained in this study indicate that broad areas of the Asahi Mountains cooled around $10 \mathrm{Ma}$. This age is consistent with the initial uplift stage of the OBR at 12-9 Ma (Nakajima et al. 2006). This may imply that the temporal uplift occurred at 12-9 Ma not only in the OBR but also in parts of the back-arc side.

\section{Computation of denudation rates}

Accurate estimation of denudation rates is not easy because the volcanic front has moved toward the fore-arc side by a few ten kilometers after the opening of the Sea of Japan (Yoshida 2009; Yoshida et al. 2013). Nonetheless, we attempted to make approximate calculations by using the conventional approach based on closure temperature and thermochronometric age considerations:

$$
\mathrm{d} D / \mathrm{d} t=\frac{T_{\mathrm{c}}-T_{\mathrm{s}}}{G t}
$$

where $\mathrm{d} D / \mathrm{d} t$ is the denudation rate averaged for the duration indicated by thermochronometric age, $T_{\mathrm{c}}$ is closure temperature, $T_{\mathrm{s}}$ is surface temperature, $G$ is geothermal gradient, and $t$ is thermochronometric age (e.g., Wagner and van den Haute 1992). Here, we calculated mean denudation rates since the timing of the AHe system closure in each locality. $T_{\mathrm{s}}$ of $10{ }^{\circ} \mathrm{C}$ was adopted, whereas $G$ was set to $30-60{ }^{\circ} \mathrm{C} / \mathrm{km}$ in the OBR and the Asahi Mountains, and to $20-40{ }^{\circ} \mathrm{C} / \mathrm{km}$ in the Abukuma Mountains (Fig. 1a). $T_{c}$ was calculated for each sample based on Dodson's (1973) method (Table 1) because $T_{\mathrm{c}}$ varies depending on the cooling rate:

$$
\begin{aligned}
& \mathrm{d} T / \mathrm{d} t=\left(T_{\mathrm{c}}-T_{\mathrm{s}}\right) / t_{\mathrm{AHe}} \\
& \tau=-\frac{R T_{\mathrm{c}}^{2}}{E_{a} \mathrm{~d} T / \mathrm{d} t} \\
& T_{\mathrm{c}}=\frac{E_{a}}{R \ln \left(A \tau D_{0} / a^{2}\right)}
\end{aligned}
$$

where $\mathrm{d} T / \mathrm{d} t$ is the cooling rate, $t_{\mathrm{AHe}}$ is the AHe age, $R$ is the gas constant $(=8.314 \mathrm{~J} / \mathrm{K} \mathrm{mol}), E \mathrm{a}$ is the activation energy $(=151.46 \mathrm{~kJ} / \mathrm{mol}), A$ is the geometric factor (=55 for sphere), $D_{0}$ is the diffusivity at infinite temperature $\left(50 \mathrm{~cm}^{2} / \mathrm{s}\right)$, and $a$ is the dimension of the diffusion domain, that is, radius of grain (arithmetic mean radius of each sample was adopted). $T_{\mathrm{c}}$ was computed by performing 10 iterative calculations of $\mathrm{d} T / \mathrm{d} t, \tau$, and $T_{\mathrm{c}}$ by 
using an appropriate initial $T_{\mathrm{c}}$ value, for example, $70{ }^{\circ} \mathrm{C}$. Errors in the denudation rates propagated from those in the weighted mean ages and geothermal gradients. The computed denudation rates are shown in Fig. 4c. The denudation rates are $0.1-0.3 \mathrm{~mm} /$ year in the Asahi Mountains, $\sim 0.1$ to $1 \mathrm{~mm} /$ year in the OBR, and $<0.1 \mathrm{~mm} /$ year in the Abukuma Mountains. The denudation rates deduced from A02-ST04, 08, 09, and 13 are less reliable owing to the possibility of later reheating, so the rates are interpreted as the upper limit of the denudation rate in each locality.

In calculating the denudation rates, we did not consider the possible warping of isotherms derived from some effects related to mountain building, for instance, advection of mass and heat due to uplift and denudation, and subsurface temperature variation brought about by topographic relief (e.g., Braun 2005; Ehlers 2005). These effects can lead to an erroneous calculation of denudation rates if linear and horizontal isotherms are assumed. Isotherm warping becomes more significant when (1) wavelength of topography is shorter (Stüwe et al. 1994), (2) topographic relief is larger (Stüwe et al. 1994; Mancktelow and Grasemann 1997), (3) denudation rate is higher (Stüwe et al. 1994; Mancktelow and Grasemann 1997),(4) closure temperature of thermochronometer is lower (Mancktelow and Grasemann 1997; Braun 2002; Ehlers and Farley 2003), and (5) a relatively long time has passed since onset of the uplift (Stüwe et al. 1994; Mancktelow and Grasemann 1997; Reiners and Brandon 2006). However, the mountains in the study area generally have moderate widths of ca $40-70 \mathrm{~km}$ (Fig. 1a), with moderately low elevation ranging from several hundred to $<2000 \mathrm{~m}$ at the maximum (Fig. 1b), and relatively slow apparent denudation rates of $0.01-1 \mathrm{~mm} /$ year as computed above. In addition, the ongoing uplift of the mountains generally initiated within the last few million years (Nakajima et al. 2006; Moriya et al. 2008). Therefore, we can justifiably exclude the effects of isotherm advection related to mountain uplift in the study area.

Shorter-term denudation and uplift rates have been reported in the study area based on other methods. Mean denudation rates within the last few tens of years were calculated to be $\sim 0.1 \mathrm{~mm} /$ year in the Abukuma Mountains and $\sim 0.5 \mathrm{~mm} /$ year in the Asahi Mountains based on relationships between altitude dispersion in drainage basins and denudation rates deduced from sediment loads in catchments (Fujiwara et al. 1999). Denudation rates over the Holocene time scale in the Abukuma Mountains were also determined to be $\sim 0.1 \mathrm{~mm} /$ year or lower based on cosmogenic nuclide data (e.g., Shiroya et al. 2010; Regalla et al. 2013; Matsushi et al. 2014). In addition, bedrock uplift rates in the last $10^{5}$ years were estimated to be $0.2-0.6 \mathrm{~mm} /$ year or higher on the eastern margin of the Abukuma Mountains (e.g., Suzuki 1989), $\sim 0.5 \mathrm{~mm}$ /year on the eastern margin of the Asahi Mountains (Miyauchi et al. 2004), and up to $0.5 \mathrm{~mm} /$ year on the western margin of the Asahi Mountains (Ikura and Ota 2003) by using present altitudes and emergent ages of marine and/or fluvial terraces.

These data indicate that shorter-term denudation rates are generally higher. In addition, bedrock uplift rates and shorter-term denudation rates are comparable in the Asahi Mountains, whereas the bedrock uplift rates are greater than the shorter-term denudation rates in the Abukuma Mountains. This observation is interpreted to imply that steady-state conditions between denudation and bedrock uplift (e.g., Ohmori 1978; Yoshikawa 1984) have been attained in the Asahi Mountains but not in the Abukuma Mountains probably owing to the slow uplift rates and later initiation of the ongoing uplift.

\section{Implications for uplift mechanism of mountains in NE Japan Arc}

The denudation rates of the OBR increase from base to peak (Fig. 4c) - even though denudation rates deduced from A02-ST04 and 08 are less reliable, these data can indicate the maximum denudation rate in each locality. This observation might also be common in the Asahi Mountains, although the computed denudation rates may not be reliable; in the two localities of the inner part of the Asahi Mountains, namely A02-ST09 and 13, denudation rates may be overestimated as discussed above (Fig. 4c). In contrast, the Kiso Range and northern part of the Akaishi Range, fault-block mountains in the SW Japan Arc, yield younger thermochronometric ages, that is, higher denudation rates, near the marginal fault(s) rather than around the ridges (Sueoka et al. 2011, 2012, $2015,2016)$. These differences in spatial denudation patterns may reflect variations in the uplift mechanism. The denudational pattern of the OBR (and Asahi Mountains?) can be explained if the bedrock uplift rate attains the maximum value at the ridges and decreases toward both bases (see Figure 12 of Sueoka et al. 2015). Such an uplift pattern may result, for example, from folding related to thick sediments, domal uplift due to magmatic intrusion, and/or localization of strain along the hotter and softer volcanic centers.

Various models have been suggested for the uplift mechanism of mountains on the back-arc side and the OBR, but these are still debatable. Some of the major uplift mechanisms suggested are as follows: folding and faulting (Kaizuka and Chinzei 1986), repeated intrusions of Quaternary magma along "hot fingers" in mantle wedges (Tamura et al. 2002), and reactivation of faults 
under compressive stress regimes (Nakajima et al. 2006). Recently, Fukahata (2016) suggested that mountains in these regions were formed owing to the localization of deformation along hot and weakened regions. In other words, considering the regional stress field changes in the NE Japan Arc (Yoshida et al. 2013), mountains orthogonal to the arc were formed on the back-arc side along "hot fingers" under NE-SW compression prior to $~ 3 \mathrm{Ma}$, whereas the arc-parallel OBR was formed along the volcanic front under E-W compression since $\sim 3 \mathrm{Ma}$ (Fukahata 2016). In addition, Shibazaki et al. (2016) illustrated that high uplift rates along the OBR can be well explained by plastic deformation based on the thermal structure of the crust and the uppermost mantle, as well as the E-W compressional tectonic regime, over 1.5 million year.

Although the detailed mechanism of mountain uplift in these regions is still debatable, it can be attributed plausibly to both tectonic and magmatic factors. Therefore, as suggested by our thermochronometric data, it is also possible that the bedrock uplift patterns of the mountains in the NE Japan Arc are different from those of the mountains in the SW Japan Arc, where volcanism is not so predominant. For verification of the previous models on mountain formation in NE Japan and gaining a more detailed understanding of the uplift mechanism of each range, it is desirable that additional $\mathrm{He}$ and FT data be acquired in combination with thermo-kinematic modeling.

\section{Interpretation of ZHe ages older than $\sim 30 \mathrm{Ma}$}

Three of the four ZHe weighted mean ages are older than the timing of the opening of the Sea of Japan (Tables 1, 2). They may reflect an uplift and exhumation episode that occurred in the East Asian continental margin prior to the opening of the Sea of Japan. In addition, the negative correlation between $\mathrm{eU}$ and $\mathrm{ZHe}$ grain ages observed for four samples (A02-ST05, 06, 08, and 13) might be also informative for reconstructing the Paleogene to the Neogene thermal histories (Fig. 2). These ZHe data may therefore have important implications for uncovering the process and mechanism of the tectonic movement of the NE Japan Arc during the opening of the Sea of Japan, as well as for uncovering the tectonic history of the NE Asia continental margin prior to the opening. It might be noteworthy that the negative correlation between $\mathrm{eU}$ and $\mathrm{ZHe}$ grain ages is only observed for samples for which young ( $<\sim 5 \mathrm{Ma})$ AHe ages are obtained. This observation suggests that these samples experienced a relatively complicated thermal history around the closure temperature of the $\mathrm{ZHe}$ system. Inversion tectonics has generally resulted in more uplift since the late Pliocene in the regions where subsidence related to rifting was dominant during the middle Miocene (e.g., Okada and Ikeda 2012; Nakajima 2013). Therefore, dispersed ZHe ages might reflect reheating due to subsidence and burial during opening of the Sea of Japan. For verification of the interpretations above, further thermochronometric studies in other localities together with other thermochronometers are required.

\section{Conclusions}

We report the first He thermochronometric results and reconstructed uplift and denudation histories from mountains across the NE Japan Arc. The major results and interpretations are as follows:

1. Weighted mean $\mathrm{AHe}$ and $\mathrm{ZHe}$ age data range between 64.3-1.5 $\mathrm{Ma}$ and 39.6-11.0 Ma, respectively. AHe ages show obvious contrast among the different morphostructural provinces: $64.3-49.6 \mathrm{Ma}$ in the Abukuma Mountains on the fore-arc side, and 11.4-1.5 Ma in the OBR along the volcanic front and the Asahi Mountains on the back-arc side.

2. In the Abukuma Mountains, slow cooling over most of the Cenozoic is estimated, which is consistent with previously reported FT ages and geomorphic observations. AHe and $\mathrm{ZHe}$ ages in the back-arc side are interpreted to generally reflect the denudation history, although reheating events due to magmatism may be a possibility in a few localities. Based on the AHe age data, onset of the uplift of the Asahi Mountains is estimated to be $\sim 10 \mathrm{Ma}$.

3. Denudation rates were calculated to be $\sim 0.1$ to $0.3 \mathrm{~mm} /$ year in the Asahi Mountains, $\sim 0.1$ to $1 \mathrm{~mm} /$ year in the OBR, and $<0.1 \mathrm{~mm} /$ year in the Abukuma Mountains. The denudation rates increase with elevation from base to ridge in the OBR (and perhaps in the Asahi Mountains), which is in contrast to the denudation patterns reported for fault-block mountains in the SW Japan Arc. The difference may imply a variation in uplift mechanisms between the two regions.

4. Although additional investigations are desirable for further verification of the interpretations presented above and for further discussion, thermochronometry is generally useful for reconstructing the uplift and denudation histories across the NE Japan Arc, a typical island arc setting, as long as the possible thermal effects of magmatism are considered carefully.

\section{Abbreviations}

FT: fission-track; He: (U-Th)/He; AHe: apatite (U-Th-Sm)/He; ZHe: zircon (UTh)/He; NE Japan Arc: Northeast Japan Arc; SW Japan Arc: Southwest Japan Arc; OBR: Ou Backbone Range. 


\section{Authors' contributions}

SS drafted the manuscript. SS and TT are responsible for the project, conducting research planning, sample collection, and data interpretation. BK performed the $(\mathrm{U}-\mathrm{Th}) / \mathrm{He}$ analyses and assisted in drafting the manuscript. All authors read and approved the final manuscript.

\section{Author details}

${ }^{1}$ Tono Geoscience Center, Japan Atomic Energy Agency, 959-31, Jorinji, Izumi-cho, Toki, Gifu 509-5102, Japan. ${ }^{2}$ Division of Earth and Planetary Sciences, Graduate School of Science, Kyoto University, Oiwake-cho, Kitashirakawa, Sakyo-ku, Kyoto, Kyoto 606-8502, Japan. ${ }^{3}$ School of Earth Sciences, University of Melbourne, Melbourne, VIC 3010, Australia.

\section{Acknowledgements}

This work was supported by the Grant-in-Aid for Scientific Research on Innovative Areas (KAKENHI No. 26109003) from the Ministry of Education, Culture, Sports, Science and Technology (MEXT). Mineral separations were carried out by Drs. T. Danhara and H. Iwano of Kyoto Fission-Track Co., Ltd. The University of Melbourne thermochronology facility is supported by the National Collaborative Research Infrastructure Strategy AuScope program. We thank S. Fukuda of Kyoto University for useful comments. We also appreciate the Tohoku Regional Environment Office for permission to collect rocks in the Bandai-Asahi National Park.

\section{Competing interests}

The authors declare that they have no competing interests.

\section{Publisher's Note}

Springer Nature remains neutral with regard to jurisdictional claims in publishedmaps and institutional affiliations.

Received: 30 January 2017 Accepted: 29 May 2017

Published online: 13 June 2017

\section{References}

Beucher R, Brown RW, Roper S, Stuart F, Persano C (2013) Natural age dispersion arising from the analysis of broken crystals: part II. Practical application to apatite (U-Th)/He thermochronometry. Geochim Cosmochim Acta 120:395-416

Braun J (2002) Quantifying the effect of recent relief changes on age-elevation relationships. Earth Planet Sci Lett 200:331-343

Braun J (2005) Quantitative constraints on the rate of landform evolution derived from low-temperature thermochronology. Rev Mineral Geochem 58:351-374

Brown RW, Beuther R, Roper S, Persano C, Stuart F, Fitzgerald P (2013) Natural age dispersion arising from the analysis of broken crystals. Part I: theoretical basis and implications for the apatite (U-Th)/He thermochronometer. Geochim Cosmochim Acta 122:478-497

Committee for Catalog of Quaternary Volcanoes in Japan (1999) Catalog of Quaternary Volcanoes in Japan. The Volcanological Society of Japan, Tokyo

Danišík M, Mclnnes BIA, Kirkland CL, McDonald BJ, Evans NJ, Becker T (2017) Seeing is believing: visualization of He distribution in zircon and implications for thermal history reconstruction on single crystals. Sci Adv 3:e1601121

Dodson MH (1973) Closure temperature in cooling geochronological and petrological systems. Contrib Mineral Petrol 40:259-274

Ehlers TA (2005) Crustal thermal processes and the interpretation of thermochronometer data. Rev Mineral Geochem 58:315-350

Ehlers TA, Farley KA (2003) Apatite (U-Th)/He thermochronometry: methods and applications to problems in tectonic and surface processes. Earth Planet Sci Lett 206:1-14

Farley KA (2000) Helium diffusion from apatite: general behavior as illustrated by Durango fluorapatite. J Geophys Res 105:2903-2914

Farley KA, Wolf RA, Silver LT (1996) The effects of long alpha-stopping distances on (U-Th)/He ages. Geochim Cosmochim Acta 60:4223-4229
Flowers RM, Ketcham RA, Shuster DL, Farley KA (2009) Apatite (U-Th)/He thermochronometry using a radiation damage accumulation and annealing model. Geochim Cosmochim Acta 73:2347-2365

Fujiwara O, Sanga T, Ohmori H (1999) Regional distribution of erosion rates over the Japanese Islands. JNC Tech Rev 5:85-93 (in Japanese with English abstract)

Fujiwara O, Yanagisawa Y, Irizuki T, Shimamoto M, Hayashi H, Danhara T, Fuse K, Iwano H (2008) Chronological data for the Middle Miocene to Pliocene sequence around the southwestern Sendai Plain, with special reference to the uplift history of the Ou Backbone Range. Bull Geol Surv Jpn 59:423-438 (in Japanese with English abstract)

Fukahata Y (2016) On the causes of across-arc mountain ranges in the back-arc region of Tohoku arc: importance of north-south compression. In: Japan Geoscience Union Meeting 2016, Abstract no SCG63-30. https://confit. atlas.jp/guide/event/jpgu2016/subject/SCG63-30/detail

Gautheron C, Tassan-Got L, Barbarand J, Pagel M (2009) Effect of alphadamage annealing on apatite $(\mathrm{U}-\mathrm{Th}) / \mathrm{He}$ thermochronology. Chem Geol 266:157-170

Gautheron C, Barbarand J, Ketcham RA, Tassan-Got L, van der Beek P, Pagel M, Pinna-Jamme R, Couffignal F, Fialin M (2013) Chemical influence on a-recoil damage annealing in apatite: implications for ( $U-T h) / H e$ dating. Chem Geol 351:257-267

Gleadow A, Harrison M, Kohn B, Lugo-Zazueta R, Phillips D (2015) The Fish Canyon Tuff: a new look at an old low-temperature thermochronology standard. Earth Planet Sci Lett 424:95-108

Goto A (2001) Formation ages of elevated peneplains of the Japanese Islands: an approach from the fission-track dating. Grant-in-Aid for Scientific Research, Report no 10440144 (in Japanese). https://kaken.nii.ac.jp/en/ grant/KAKENHI-PROJECT-10440144/

Guenthner WR, Reners PW, Ketcham RA, Nasdala L, Giester G (2013) Helium diffusion in natural zircon: radiation damage, anisotropy, and the interpretation of zircon (U-Th)/He thermochronology. Am J Sci 313:145-198

Hashimoto M (1990) Horizontal strain rates in the Japanese Islands during interseismic period deduced from geodetic surveys (part I): Honsyu, Shikoku and Kyushu. Zishin (J Seism Soc Japan, 2nd Ser) 43:13-26 (in Japanese with English abstract)

Hourigan JK, Reiners PW, Brandon MT (2005) U-Th zonation-dependent alpha-ejection in (U-Th)/He chronometry. Geochim Cosmochim Acta 69:3349-3365

House MA, Farley KA, Stockli D (2000) Helium chronometry of apatite and titanite using Nd-YAG laser heating. Earth Planet Sci Lett 183:365-368

Ikeda Y (1996) Implications of active fault study for the present-day tectonics of the Japan arc. Act Fault Res 15:93-99 (in Japanese with English Abstract)

Ikeda Y (2014) Strain buildup in the Northeast Japan orogen with implications for gigantic subduction earthquakes. Episodes 37:234-245

Ikeda Y, Okada S, Tajikara M (2012) Long-term strain buildup in the Northeast Japan arc-trench system and its implications for gigantic strain-release events. J Geol Soc Jpn 118:294-312 (in Japanese with English Abstract)

Ikura K, Ota Y (2003) Holocene marine terraces along the west coast of the Asahi Mountains, northern Japan, and their tectonic implications. J Geogr (Chigaku Zasshi) 112:394-405 (in Japanese with English abstract)

Jolivet L, Tamaki K, Fournier M (1994) Japan Sea, opening history and mechanism: a synthesis. J Geophys Res 99:22237-22259

Kaizuka S, Chinzei K (eds) (1986) Mountais in Japan. Iwanami, Tokyo (in Japanese)

Ketcham RA, Donelick RA, Carlson WD (1999) Variability of apatite fission-track annealing kinetics:III. Extrapolation to geological time scales. Am Mineral $84: 1235-1255$

Kimura K (1994) The late Cenozoic denudation history of the northern part of the Abukuma Highlands, northeastern Japan. Quat J Geogr (Kikan Chirigaku) 46:1-18 (in Japanese with English abstract)

Koike K (1969) Geomorphological development of the Abukuma Mountains and its surroundings, Northeast Japan. Jpn J Geol Geogr 40:1-40 
Kondo H, Shuto K, Fukase M (2000) An AFC (assimilation and fractional crystallization) process as the petrogenesis of andesites from the Pliocene Myojin-iwa Formation, the back-arc side of the Northeast japan: combined major-and trace-element and Sr-Nd isotope constraints. J Geol Soc Jpn 106:426-441

Ludwig KR (2012) User's manual for Isoplot 3.75: a geochronological toolkit for Microsoft Excel. Berkeley Geochronology Center Sspecial publication no 5. Berkeley Geochronological Center, Berkeley. http://www.bgc.org/ isoplot_etc/isoplot.html

Mancktelow NS, Grasemann B (1997) Time-dependent effects of heat advection and topography on cooling histories during erosion. Tectonophysics 270:167-195

Matsushi Y, Matsuzaki H, Makino H (2014) Testing models of landform evolution by determining the denudation rates of mountainous watersheds using terrestrial cosmogenic nuclides. Trans Jpn Geomophol Union 35:165-185 (in Japanese with English abstract)

McDowell FW, McIntosh WC, Farley KA (2005) A precise ${ }^{40} \mathrm{Ar}-{ }^{39} \mathrm{Ar}$ reference age for the Durango apatite (U-Th)/He and fission-track dating standard. Chem Geol 214:249-263

Minoura K, Hasegawa A (1992) Crustal structure and origin of the northeast Japan arc. Is| Arc 1:2-15

Miyauchi T, Hirayanagi Y, Imaizumi T (2004) Late Quaternary activity of the western marginal fault zone of Nagai Basin, Northeast Japan. Act Fault Res 24:53-61 (in Japanese with English abstract)

Moriya T, Chinzei K, Nakajima T, Danhara T (2008) Uplift of the Dewa Hills recorded in the Pliocene paleogeographic change of the western Shinjo basin, Yamagata Prefecture. J Geol Soc Jpn 114:389-404 (in Japanese with English abstract)

Nakajima T (2012) Description of unconformities and pyroclastic key beds in the Yuda Basin, Iwate Prefecture, and their implications for the uplift of the Ou Backbone Range. Earth Sci (Chikyu Kagaku) 66:69-83 (in Japanese with English abstract)

Nakajima T (2013) Late Cenozoic tectonic events and intra-arc basin development in northeast Japan. In: Itoh Y (ed) Mechanism of sedimentary basin formation - multidisciplinary approach on active plate margins. InTech, Rijeka, pp 153-189. doi:10.5772/56706

Nakajima T, Danhara T, Iwano H, Chinzei K (2006) Uplift of the Ou Backbone Range in Northeast Japan at around $10 \mathrm{Ma}$ and its implication for the tectonic evolution of the eastern margin of Asia. Paleogeogr Palaeoclim Palaeocol 241:28-48

Nakamura Y (1963) Base levels of erosion in the central part of the Kitakami Mountainland. Sci Rep Tohoku Univ 7th Ser (Geogr) 12:85-109

Nakata T, Imaizumi T (eds) (2002) Digital active fault map of Japan. University of Tokyo Press, Tokyo (in Japanese with English Abstract)

Nishimura T (2014) Pre-, Co-, and post-seismic deformation of the 2011 Tohoku-oki earthquake and its implication to a paradox in short-term and long-term deformation. J Disaster Res 9:1

Ohira H, Honda T (1999) Fission track age Th/ $\mathrm{U}$ abundance ratio of zircon from the Tanigawadake Pluton, North Fossa Magna, Central Japan. FT News Lett 12:61-63 (in Japanese)

Ohmori H (1978) Relief structure of the Japanese mountains and their stages in geomorphic development. Bull Dep Geogr Univ Tokyo 10:31-85

Ohtani T, Shigematsu N, Fujimoto K, Tomita T, Iwano H (2004) Geochronological constraint on the brittle-plastic deformation along the Hatagawa Fault Zone, NE Japan. Earth Planets Space 56:1201-1207. doi:10.1186/ BF03353341

Okada S, Ikeda Y (2012) Quantifying crustal extension and shortening in the back-arc region of Northeast Japan. J Geophys Res 117:B01404. doi:10.10 29/2011JB008355

Okamura Y, Watanabe M, Morijiri R, Satoh M (1995) Rifting and basin inversion in the eastern margin of the Japan Sea. Isl Arc 4:166-181

Otofuji Y, Matsuda T, Noda S (1985) Paleomagnetic evidence for Miocene counter-clockwise rotation of Northeast Japan - rifting process of the Japan arc. Earth Planet Sci Lett 75:265-277

Ozawa S, Nishimura T, Suito H, Kobayashi T, Tobita M, Imakiire T (2011) Coseismic and postseismic slip of the 2011 magnitude-9Tohoku-Oki earthquake. Nature 475:373-377. doi:10.1038/nature10227
Phillips D, Matchan EL (2013) Ultra-high precision ${ }^{40} \mathrm{Ar} /{ }^{39} \mathrm{Ar}$ ages for Fish Canyon Tuff and Alder Creek Rhyolite sanidine: new dating standards required? Geochim Cosmochim Acta 121:229-239

Regalla C, Kirby E, Fisher D, Bierman P (2013) Active forearc shortening in Tohoku, Japan: constraints on fault geometry from erosion rates and fluvial longitudinal profiles. Geomorph 195:84-98

Reiners PW, Brandon MT (2006) Using thermochronology to understand orogenic erosion. Ann Rev Earth Planet Sci 34:419-466

Reiners PW, Ehlers TA, Zeitler PK (2005) Past, present, and future of thermochronology. Rev Mineral Geochem 58:1-18

Sato H (1994) The relationship between late Cenozoic tectonic events and stress field and basin development in northeast Japan. J Geophys Res 99:22261-22274

Sato H, Kato N (2010) Crustal structure and earthquake source faults on the backarc side of northern Honshu, Japan. J Geol Soc Jpn 116:592-601 (in Japanese with English abstract)

Sato H, Iwasaki T, Kawasaki S, Ikeda Y, Matsuta N, Takeda T, Hirata N, Kawanaka $\mathrm{T}$ (2004) Formation and shortening deformation of a back-arc rift basin revealed by deep seismic profiling, central Japan. Tectonophysics 388:47-58

Shibazaki B, Okada T, Muto J, Matsumoto T, Yoshida T, Yoshida K (2016) Heterogeneous stress state of island arc crust in northeastern Japan affected by hot mantle fingers. J Geophys Res Solid Earth 121:3099-3117. doi:10.100 2/2015JB012664

Shiroya K, Yokoyama Y, Matsuzaki H (2010) Quantitative determination of long-term erosion rates of weathered granitic soil surfaces in western Abukuma, Japan using cosmogenic ${ }^{10} \mathrm{Be}$ and ${ }^{26} \mathrm{Al}$ depth profile. Geochem J 44:e23-e27

Shuster DL, Flowers RM, Farley KA (2006) The influence of natural radiation damage on helium diffusion kinetics in apatite. Earth Planet Sci Lett 249:148-161

Spiegel C, Kohn B, Belton D, Berner Z, Gleadow A (2009) Apatite (U-Th-Sm)/He thermochronology of rapidly cooled samples: the effect of He implantation. Earth Planet Sci Lett 285:105-114

Stüwe K, White L, Brown R (1994) The influence of eroding topography on steady-state isotherms. Application to fission track analysis. Earth Planet Sci Lett 124:63-74

Sueoka S, Kohn BP, Ikeda Y, Kano K, Tsutsumi H, Tagami T (2011) Uplift and denudation history of the Akaishi Range based on low-temperature thermochronologic methods. J Geogr (Chigaku Zasshi) 120:1003-1012 (in Japanese with English abstract)

Sueoka S, Kohn BP, Tagami T, Tsutsumi H, Hasebe N, Tamura A, Arai S (2012) Denudation history of the Kiso Range, central Japan, and its tectonic implications: constraints from low-temperature thermochronology. Is| Arc 21:32-52

Sueoka S, Tsutsumi H, Tagami T (2015) Development of low-temperature thermochronology and its application to uplift and denudational history of Japanese mountains. Earth Sci (Chikyu Kagaku) 69:47-70 (in Japanese with English abstract)

Sueoka S, Tsutsumi H, Tagami T (2016) New approach to resolve the amount of Quaternary uplift and associated denudation of the mountain ranges in the Japanese Islands. Geosci Front 7:197-210. doi:10.1016/j. gsf.2015.06.005

Suzuki T (1989) Late Quaternary crustal movements deduced from marine terraces and active faults, Joban coastal region, northeast Japan. Geogr Rep Tokyo Metrop Univ 24:31-42

Tamura Y, Tatsumi Y, Zhao D, Kido Y, Shukuno H (2002) Hot fingers in the mantle wedge: new insights into magma genesis in subduction zones. Earth Planet Sci Lett 197:105-116

Tanaka A, Yamano M, Yano Y, Sasada M (2004) Geothermal gradient data in and around Japan, digital geoscience map DGM P-5. Geological Survey of Japan, Tsukuba

Umeda K, Komatsu R, Nakatsuka N (1999) Geothermal structure based on temperature logging data of boreholes in Japan. JNC Tech Rev 2:29-36 (in Japanese with English abstract)

Vermeesch P, Seward D, Latkoczy C, Wipf M, Günther D, Baur H (2007) a-emitting mineral inclusions in apatite, their effect on (U-Th)/He ages, and how to reduce it. Geochim Cosmochim Acta 71:1737-1746 
Wagner GA, van den Haute P (1992) Fission-track dating. Enke Stuttg Ger. doi:10.1007/978-94-011-2478-2

Wakita K, Igawa T, Takarada S (2009) Seamless geological map of Japan at a scale of 1:200,000 DVD edition. Digital Geoscience Map G-16. Geologica Survey of Japan, AIST, Tsukuba

Wessel P, Smith WHF (1991) Free software helps map and display data. EOS Trans AGU 72:441. doi:10.1029/90EO00319

Yanai S, Aoki K, Akahori Y (2010) Opening of Japan Sea and major tectonic lines of Japan: mTL, TTL and Fossa Magna. J Geogr (Chigaku Zasshi) 119:1079-1124 (in Japanese with English abstract)

Yoshida T (2009) Late Cenozoic magmatism in the northeast Honshu Arc Japan. Earth Sci (Chikyu Kagaku) 63:269-288 (in Japanese with English abstract)
Yoshida T, Kimura Jl, Yamada R, Acocella V, Sato H, Zhao D, Nakajima J, Hasegawa A, Okada T, Honda S, Ishikawa M, Prima OKA, Kudo T, Shibazaki B, Tanaka A, Imaizumi T (2013) Evolution of late Cenozoic magmatism and the crust-mantle structure in the NE Japan Arc. In: Gómez-Tuena A, Straub SM, Zellmer GF (eds) Orogenic andesites and crustal growth. Special publications, vol 385. Geological Society, London, pp 335-387. doi:10.1144/SP385.15

Yoshikawa T (1984) Geomorphology of tectonically active and intensely denuded regions. Geogr Rev Jpn 57A:691-702 (in Japanese with English abstract)

\section{Submit your manuscript to a SpringerOpen ${ }^{\circ}$ journal and benefit from:}

- Convenient online submission

- Rigorous peer review

- Open access: articles freely available online

- High visibility within the field

- Retaining the copyright to your article

Submit your next manuscript at $\mathbf{s p r i n g e r o p e n . c o m ~}$ 